\title{
Effect of temperature and relative humidity on plasma and gonadal testosterone concentrations in camels (Camelus dromedarius)
}

\author{
S. Gombe and D. Oduor-Okelo \\ Department of Animal Physiology, University of Nairobi, P.O. Box 30197, Nairobi, Kenya
}

The breeding seasons of camels vary geographically (see Novoa, 1970), suggesting that environmental factors affect the temporal pattern of reproduction in these species. Gomes, Butler \& Johnson (1971) found that a high ambient temperature had the effect of reducing testosterone production in the ram and it therefore seemed possible that the effect of the environment in the reproductive cycle of the camel was a consequence of thermal stress. In the present study the ambient temperature $\left(20-30^{\circ} \mathrm{C}\right)$ was only moderate but the concomitant high humidity would have increased the thermal stress for an animal whose normal habitat is a hot arid environment.

Four prepubertal camels (Camelus dromedarius) about 4 years old were bled by jugular venepuncture three times a week for 12 months. The heparinized plasma was kept at $-20^{\circ} \mathrm{C}$ until extracted and assayed. After 12 months, the testes were removed surgically under etorphine anaesthesia and $5 \mathrm{~g}$ portions were homogenized after adding $0.6 \mathrm{nCi}\left[{ }^{3} \mathrm{H}\right]$ testosterone as tracer $(\mathrm{sp}$, act. $80-110 \mathrm{Ci} / \mathrm{mol}$ : Radiochemical Centre, Amersham). The homogenate was refluxed twice with $50 \mathrm{ml}$ ethanol for $20 \mathrm{~min}$. The combined extract was flash evaporated to dryness at $60^{\circ} \mathrm{C}$. The residue was dissolved in $10 \mathrm{ml}$ diethyl ether and washed twice with $2 \mathrm{ml}$ glass-distilled water, evaporated to dryness and redissolved in $1 \mathrm{ml}$ ethanol. Aliquots $(200 \mu \mathrm{l})$ of the ethanolic extract were purified by two dimensional t.l.c. on silica gel F254 (Gombe \& Kayanja, 1974), eluted and redissolved in $1 \mathrm{ml}$ aliquots of ethanol.

Other testes and epididymides were fixed in $5 \%$ formalin and routinely processed to give $7 \mu \mathrm{m}$ sections stained with haematoxylin and eosin.

Aliquots $(1 \mathrm{ml})$ of each plasma sample were extracted twice with $5 \mathrm{ml}$ diethyl ether. The aqueous layer was frozen on solid $\mathrm{CO}_{2}$ and the supernate decanted into other vials. The combined supernates were washed with $2 \mathrm{ml}$ glass-distilled water and evaporated to dryness in vacuo. The steroid residue was dissolved in $1 \mathrm{ml}$ ethanol and kept at $-20^{\circ} \mathrm{C}$ until assayed.

Pooled plasma from the camels was stripped of endogenous steroids by thorough mixing with dextran-coated charcoal over a rota mixer. After centrifugation the supernate was divided into $1 \mathrm{ml}$ aliquots. Known quantities of authentic testosterone $(10,20,50,200$ and $500 \mathrm{pg}$ ) were added in triplicate to the aliquots of stripped plasma, incubated for $20 \mathrm{~min}$ at $37^{\circ} \mathrm{C}$ and extracted as above. The testosterone content of the extracts was determined by the radioimmunoassay method described by Coyotupa, Parlow \& Abrahams (1972). The determined values of 7.8, 15.8, 43, 170 and $475 \mathrm{pg}$, respectively, represented an overall recovery of $85 \pm 3 \%$ (S.E.M.) which was comparable to that obtained by Gombe \& Ndeti (1976) from human plasma. The working range of the assay was 5 to 500 pg.

Gonadal and plasma testosterone concentrations of the experimental material were determined using this procedure. The antiserum used, S-741-2 testosterone-3-oxime-HSA, cross-reacts significantly only with $5 \alpha$-dihydrotestosterone. Thus plasma values strictly represent both testosterone and $5 \alpha$-dihydrotestosterone whilst the t.l.c.-purified gonadal values represent testosterone alone. The scintillation fluid was PPO-POPOP and the counting was done in a Packard Scintillation Counter (Model 3300).

Climatological data were obtained from three adjoining meteorological stations all within a radius of 5 miles, and the means from the three stations were used to represent the Nairobi weather (Table 1).

Mean ( \pm S.E.M.) gonadal weights $(17 \cdot 8 \pm 4 \cdot 1 \mathrm{~g})$ and testosterone concentrations $(7 \cdot 9 \pm 3.3 \mathrm{ng} / \mathrm{g}$ wet weight) were low, reflecting the immaturity of the camels. Although the Leydig cells were well developed, the seminiferous tubules were still solid and the epididymides devoid of spermatozoa. 
Table 1. Variation of plasma testosterone in 4 camels with temperature and relative humidity

\begin{tabular}{|c|c|c|c|c|}
\hline & $\begin{array}{c}\text { Plasma } \\
\text { testosterone } \\
(\mathrm{pg} / \mathrm{ml})\end{array}$ & $\begin{array}{c}\text { Max. } \\
\text { ambient } \\
\text { temp. }\left({ }^{\circ} \mathrm{C}\right)\end{array}$ & $\begin{array}{c}\text { Relative } \\
\text { humidity }\end{array}$ & $\begin{array}{c}\text { Temperature: } \\
\text { relative } \\
\text { humidity }\end{array}$ \\
\hline \multicolumn{5}{|l|}{1974} \\
\hline August & $63.6 \pm 6.5$ & $21.7 \pm 0.5$ & $0.84 \pm 0.0004$ & $25 \cdot 83$ \\
\hline September & $127 \cdot 5 \pm 15 \cdot 2$ & $23.0 \pm 0.5$ & $0.84 \pm 0.0004$ & $27-38$ \\
\hline October & $244.0 \pm 27.9$ & $25 \cdot 3 \pm 0.7$ & $0.75 \pm 0.0002$ & $33 \cdot 73$ \\
\hline November & $82 \cdot 3 \pm 11 \cdot 1$ & $23.5 \pm 0.5$ & $0.84 \pm 0.0001$ & 27.98 \\
\hline December & $272 \cdot 6 \pm 48 \cdot 5$ & $25 \cdot 0 \pm 0.5$ & $0.71 \pm 0.0000$ & $35 \cdot 21$ \\
\hline \multicolumn{5}{|l|}{1975} \\
\hline January & $127 \cdot 4 \pm 17 \cdot 3$ & $26.8 \pm 0.5$ & $0.65 \pm 0.0000$ & $41 \cdot 23$ \\
\hline February & $75 \cdot 0 \pm 8 \cdot 0$ & $28.0 \pm 0.4$ & $0.66 \pm 0.0001$ & $42 \cdot 42$ \\
\hline March & $68 \cdot 8 \pm 6.5$ & $28.7 \pm 0.2$ & $0.72 \pm 0.0001$ & $39 \cdot 86$ \\
\hline April & $99 \cdot 2 \pm 7 \cdot 2$ & $25.4 \pm 0.6$ & $0.82 \pm 0.0001$ & 30.98 \\
\hline May & $125.6 \pm 6.0$ & $23.6 \pm 0.5$ & $0.84 \pm 0.0000$ & $28 \cdot 10$ \\
\hline June & $55.0 \pm 9.5$ & $21.9 \pm 0.7$ & $0.84 \pm 0.0001$ & 26.07 \\
\hline July & $169 \cdot 1 \pm 18 \cdot 4$ & $22.3 \pm 0.6$ & $0.83 \pm 0.0004$ & $26 \cdot 87$ \\
\hline
\end{tabular}

Low values of plasma androgens were found in all the camels; the 12-month means of the four animals being $68 \cdot 0 \pm 9 \cdot 2,79 \cdot 3 \pm 16 \cdot 4,152 \cdot 6 \pm 19 \cdot 8$ and $157 \cdot 9 \pm 46 \cdot 7 \mathrm{pg} / \mathrm{ml}$. There was, however, a well defined monthly fluctuation (Table 1 ). These monthly means showed a high correlation with the maximum ambient temperature $\left(r=0.92\right.$ below $25^{\circ} \mathrm{C}$ and $r=0.79$ above $\left.25^{\circ} \mathrm{C}\right)$. Further analysis revealed a quadratic relationship between the plasma androgen concentration and the temperature/ relative humidity ratio:

$$
\text { Plasma testosterone }=-1894+122 \cdot 7 \frac{T_{\max }}{\mathrm{RH}}-1 \cdot 8 \frac{\left(T_{\max }\right)^{2}}{\mathrm{RH}}
$$

where $T_{\max }=$ maximum ambient temperature in ${ }^{\circ} \mathrm{C}$ and $\mathrm{RH}=$ relative humidity expressed as a fraction of 1 .

Peak androgen production occurred at $25.5^{\circ} \mathrm{C}$ and a relative humidity of 0.75 . At any temperature, a relative humidity value greater than 0.75 depressed plasma testosterone considerably (e.g. compare values for November with those in October and December).

Considerable fluctuations in testosterone levels have been noted before puberty for many animals, and it is possible that some of the fluctuations noted in this study were due to the prepubertal state of the camels. None the less, the fact that the monthly variations coincided in the four animals suggests that some environmental factor was operative. Low values of plasma testosterone have been recorded in November 1975 in Nairobi for adult donkeys (S. Gombe and C. B. Katongole, unpublished). The observation of Gomes et al. (1971) that high ambient temperature is detrimental to steroidogenesis in rams and the present statistical correlation between plasma androgens and the temperature/relative humidity ratio suggest that 'heat load' may be an important environmental factor influencing gonadal function in the tropics, i.e. high relative humidity exacerbates the detrimental effect of temperature on Leydig cell function.

\section{References}

Coyotupa, J., Parlow, A.F. \& Abrahams, E. (1972) Simultaneous radioimmunoassay of plasma testosterone and dihydrotestosterone. Analytical Letters 5, 329-340.

Gombe, S. \& KaYANJA, F.I.B. (1974) Ovarian progestins in Masai giraffe (Giraffa camelopardalis). J. Reprod. Fert. 40, 45-50.

Gompe, S. \& Ndeti, C.T. (1976) Plasma testosterone and progesterone levels in adult East Africans. $E$. $A f r$. med.J. 53, 43-46.

Gomes, W.R., ButLER, W.R. \& Johnson, A.D. (1971) Effect of elevated ambient temperature on testis and blood levels and in vitro biosynthesis of testosterone in the ram. J. Anim. Sci. 33, 804-807.

NovoA, C. (1970) Reproduction in Camelidae, a review. J. Reprod. Fert. 22, 3-20. 